\title{
Katarzyna Turczyn
}

Independent researcher

\section{Educational Activities of the National Film Archive in Warsaw Connected with Pre-World War II Films}

In the present article I am going to discuss educational activities connected with pre-World War II films conducted by the National Film Archive in Warsaw (and their educational value). I am going to focus on three silent films: Mania. Die Geschichte einer Zigarettenarbeiterin [Mania. The Story of a Cigarette Factory Worker] (1918, dir. Eugen Illés), Pan Tadeusz [Sir Thaddeus] (1928, dir. Ryszard Ordyński) and Zew morza [The Call of the Sea] (1927, dir. Henryk Szaro). All three were digitally reconstructed as part of the Nitrofilm project, conducted by the National Film Archive in 2008-2014. My analysis will tackle such issues as how knowledge of silent films is transmitted to the audience as well as what educational goals can be achieved with the use of silent films. For a theoretical framework, I am going to reflect on how the changing function of film repositories, since technological progress in film renovation and digitalisation has made sharing film heritage into a key issue for film museums and repositories. I will also touch upon issues related to the question of authenticity (with respect to both screenings and films) - which is of special importance with regards to reconstructed films and contemporary strategies of presentation.

\section{Silent Films in the Collection of the National Film Archive in Warsaw}

The Film Archive in Warsaw was created on 29 April 1955. In 1961, the institution was renamed as the Central Film Archive, only to be renamed again in 1970 as the Polish Film Archive. In 1987, after being entered into the register of national culture institutions, it became the National Film Archive (Filmoteka Narodowa). ${ }^{1}$ Throughout the years, the institution collected copies of all feature films released

On 1 June 2017, the National Film Archive was merged with the National Audiovisual Institute, becoming FINA: The National Film Archive - Audiovisual Institute (FINA: Filmoteka Narodowa Instytut Audiowizualny) [editor's note]. 
in Poland, as well as scripts, posters and tapes with documentary films and selected foreign films screened in Poland.

The breakthrough for the pre-World War II film collection stored by the National Film Archive as well as for silent film education came in 2003 together with the organisation of Silent Film Festival. Its subsequent editions have gradually augmented audiences' knowledge on films made in the first three decades of the $20^{\text {th }}$ century. The popularity of the festival translated into an increase in the economic and symbolic value of silent films and all related materials, kept in archives and museum storerooms. The peak in public interest came in 2006 with the discovery of the third existing copy of Pan Tadeusz in the attic of a private home in Wroclaw (the first copy known to be in existence was donated in 1955 by the Film School in Lodz and the second one was bought from a private individual in 1957). This event stimulated interest in silent cinema in Poland to such an extent that a National Film Archive filmographer met with a favourable response when she attempted to secure funds for rescuing Polish pre-World War II cinema heritage. As a result, in 2008 "the Nitrofilm: Conservation and Digitalisation of Pre-World War II Feature Films in the National Film Archive in Warsaw" project was initiated, cofinanced from the European Regional Development Fund within the Operational Programme Infrastructure and Environment, Priority Axis XI: Culture and Cultural Heritage. The chief aim of the project was to "preserve interminably the most precious examples of Polish pre-World War II cinema". Project implementation was prolonged by 6 months within the same funds and it was finally completed in the second half of 2014. During its duration of almost five years, the National Film Archive specialists conserved and digitalised 43 films included in the project. Three silent films underwent full reconstruction; the works on each one of them took about a year. They were subsequently presented at official re-premieres, accompanied with specially commissioned original music played live and other special events. In September 2011, Mania. Die Geschichte einer Zigarettenarbeiterin was presented, accompanied by Jerzy Maksymiuk's music in the Warsaw Philharmonic; the film was later screened in ten European capitals and inaugurated the Polish EU presidency. The re-premiere of Pan Tadeusz with Tadeusz Woźniak's music coincided with the opening of Iluzjon (the restored cinema of the National Film Archive) in November 2012 and was linked with screenings of other preWorld War II films as well as lectures on Pan Tadeusz and silent cinema in general. A year later, in November 2013, Zew morza re-premiered with Krzesimir Dębski's music. The event was accompanied by the international conference "Digital vs. Original. A New Source of History".

\section{The Role of Film Museums in Shaping Cultural Heritage}

Following Barbara Kirshenblatt-Gimblett's suggestion, it is possible to treat heritage as "a mode of cultural production" (2004, pp. 1-8), which increases the value of sources and monuments. Sources and monuments undergo selection and 
transformation processes, leading to the creation of an exhibition educating about the past. Pre-World War II films become an exhibition pieced together from fragments of film tape. In order to perform their role as heritage mediators, museums organise objects, transforming them from monuments to exhibits, which enables their correct interpretation (Kirshenblatt-Gimblett, 2004, pp. 7-8). Museum exhibits usually perform informative functions but a cinema-museum such as Iluzjon is an example of applied museology, constituting its identity as a museum through the action of exhibiting. Film screenings (including re-premieres) can thus be treated as an exhibition which not only educates viewers but also encourages them to become involved. A museum is responsible for shaping heritage but its functions are not limited to education, identity creation, intellectual development, heritage protection, etc. Nowadays, museums should also cater to their stakeholders' need for "pop-cultural pleasures". Modern re-premieres of silent films serve precisely this function, while at the same time they also create audiences and enliven the space of the museum.

The selection of these particular three films by the National Film Archive to be fully reconstructed and used for promoting the project reveals the contemporary mechanism of culture, heritage and politics of memory. The decision to use silent films was based on marketing arguments. As lesser known works, absent on television, they were assumed to be more likely to awake curiosity. In addition, the re-premieres were to be accompanied by live music, written especially for the occasion, which increased their rank as cultural events. The goal was to make the re-premieres stand out from similar initiatives. It should be noted, however, that these efforts aimed at popularisation of silent cinema result in only a perfunctory knowledge of a given work, which may sometimes negatively impact on the educational effect of such an initiative.

Reconstruction work in the National Film Archive is divided into a number of stages. First, a filmographer reviews the material and decides which film reels belong to which film. This may seem like an easy task but in fact some materials are mislabelled or have no label at all, which means that first they need to be identified. The outcome of this stage determines the initial material to work with on a given film. A single film in the archive is always composed of several film reels, usually stored in several copies. The filmographer decides on the order of scenes and whenever a scene is found to have more than one version, they also choose which version is to be digitally reconstructed and included in the final restored product. At times, scenes are joined together (clearly long after the film was made) in a chaotic order or only simulating the recreation of the original concept; sometimes creating an entirely different story. In such cases, filmographers rely on archives and documents to recreate the original script. Out of the three films discussed here, the most difficult to reconstruct was Pan Tadeusz- before it was restored, only 44 minutes from the original length of about three hours were known and shown (after the reconstruction, the film is 124 minutes long). The primary material was preserved in many isolated fragments, so the filmographers needed to 
carefully analyse them against Mickiewicz's text, and thus, knowing the cast and recognising individual scenes, they decided on the most likely original order. Their actions fully represented the archival activity of a museum, whose main goal is to prepare the pieces of art of the heritage to be shown to the public.

The role of the National Film Archive as a museum is also expressed through adjusting films and their screenings to the requirements of contemporary audiences; often marketing them as cultural events and sources of entertainment. Silent film screenings attract many more viewers when they are accompanied by live music. Therefore, in order to make sure that silent film screenings remain competitive cultural events, the Iluzjon cinema seldom shows them with pre-recorded music tracks and tries to make sure that they are always accompanied by a band or an orchestra. While working on the Nitrofilm project, the decision was taken to commission new music which could make the screenings more attractive and add more artistic value to the event.

In Iluzjon, Pre-World War II sound films are also screened solely in digitally restored versions in order to make sure that the quality of sound and image does not diminish the spectators' enjoyment. Initially, these screenings were only organised as accompanying events, as the managing board feared they might not be attractive enough for viewers in their own right. The situation partially changed after the Nitrofilm project was completed - since December 2014, every month the cinema presents one film from among those which underwent reconstruction as part of the project.

\section{Around Education - Educators' Perspective vs. Spectators' Perspective $^{2}$}

The National Film Archive staff seemed to agree that most pre-World War II films were preserved in such a state that would make them inadequate and unattractive for modern viewership; hence, proper conservation and some special ways of screening are needed to make them appealing. Favourable opinions of viewers concerning the organised events seemed to confirm the hypothesis that some additional attractions were needed in order to draw audiences. The viewers were not satisfied, however, with the amount of knowledge they gained via various accompanying events (such as exhibitions and short introductory lectures) and expressed a desire to learn more about the "original" form of these films. It could be suggested, therefore, that the ideas about viewer expectations held by cultural institutions might be inaccurate or simply outright wrong. The screenings were prepared

\footnotetext{
Comments included in this section of the article are based on my anthropological research in the National Film Archive in the years 2013-2015, using methods such as ethnographic interview (30 interviews) and participant observation. Research findings were also presented in my MA thesis titled Zbiorowe konstruowanie dziedzictwa audiowizualnego na przyktadzie projektu Nitrofilm $w$ Filmotece Narodowej [Collective Creation of Audiovisual Heritage on the Example of the Nitrofilm Project in the National Film Archive] written under the supervision of Professor Magdalena Zowczak in the Institute of Ethnology and Cultural Anthropology at the University of Warsaw.
} 
without any attempt to learn about viewers needs and preferences; as a result, the final effect did not meet all expectations.

Films presented at re-premieres, special events, festivals and conferences were preceded by short introductory talks. All of those talks involved some explanations about the ways of working with film in the Nitrofilm project and a review of actions undertaken for the given title. Describing the works related to film stock, the speakers would focus on the material aspect of film. Project participants believed this information to be indispensable, while not all of the viewers shared that idea. Some viewers (five interviewees, mostly educated in humanities - history of art, archaeology) indeed treated it as necessary for correct (in their view) and full understanding of cinematic works but the rest (about three quarters of all interviewed people), while appreciating such explanations, did not deem them essential in any respect.

The rest of the introductory talks concerned films as works of art and were not considerably different from talks accompanying screenings of contemporary films. This could be described as artistic descriptions or reviews supported with interesting pieces of information. The National Film Archive staff members, predominantly filmographers, shared their knowledge with the audience. They discussed films, people involved in their making and locations, quoting film set stories, actors' biographies, as well as pre-World War II gossip and scandals. Not all viewers wanted to learn these things prior to the screening, however. Those who preferred to learn them after the screening were both laymen and film specialists. This reveals their approach to old films as works that should be decipherable by modern viewers, as film conventions have not changed that much over the years. Also viewers who appreciated introductory talks agreed that at least part of the talks could be delivered after the screening, so as to avoid disclosing the story. According to the viewers, this would enable them to watch the films without forming prior judgements. This is yet more proof that spectators do not treat silent film screenings as admiring monuments but rather as a form of entertainment.

In order to fulfil educational functions also in the case of film screenings unaccompanied by introductory talks, the films were supplemented by short introductory materials (on film stock or in digital form), which are described in the following statement:

Introductory text is very important; I don't know if you noticed... it says what film it is and how many copies were used to compose it, why part of it is in full colour, and part in black-and-white. [...] But we wanted to make sure that the audience know that what they are about to see is not the original film, that some frames are missing, things are missing, there is always something missing in these films. [...] And people need to know this. Also, this film was digitalised; not many people know what it means; they can't tell the difference between film stock and digital copies. So there have to be those introductory credits, that's the style now (Interview no. 1, 2013). 
Exhibitions prove how important screening space is and how much it influences the reception of a film. Mania re-premiered in the Warsaw Philharmonic, because the Iluzjon cinema was closed due to renovation works and the temporary cinema in the National Library did not have the space to host such an event. Mania was not accompanied by an exhibition; this format was only used for re-premieres of Pan Tadeusz and Zew morza in Iluzjon. The exhibitions made use of touchscreen monitors belonging to the cinema; in other locations where the films were screened there was usually no such equipment and the digital exhibitions could not be presented. It seems, therefore, that access to heritage presented in this way is limited to a narrow group. It should also be said that films restored within the Nitrofilm project are seldom shown anywhere outside Iluzjon. The only exception is Pan Tadeusz, released on DVD by the National Film Archive in 2012 (together with a documentary on the reconstruction process [Pan Tadeusz - Reaktywacja <Pan Tadeusz - Reloaded>, 2012, dir. Marek Maldis]) and posted online at Pantadeusz.tvp.pl ${ }^{3}$; recently, Zew morza was also made available on the website of Ninateka (Narodowy Instytut Audiowizualny [The National Audiovisual Institute]). On Iluzjon's website, one may access exhibitions concerning one silent film (Zew morza) and two sound films (Jadzia [1936, dir. Mieczysław Krawicz] and Sportowiec mimo woli [A Reluctant Sportsman; 1939/1940, dir. Mieczysław Krawicz]), although all three are incomplete. On the Google Cultural Institute platform it is possible to watch an exhibition concerning the Nitrofilm project itself, titled "Silent films: second life. Conservation and digitalisation of the oldest films stored in the National Film Archive in Warsaw". Making the exhibitions available online without any loss of their value was possible solely thanks to their fully digital form - which, of course, excludes using tangible artefacts and museum objects (Sujecki, 2005, p. 288). Such an approach, however, can lead to overlooking the material aspect of heritage. In order to prevent this, the exhibitions include information about the Nitrofilm project's development, film stock damage, film works, conservation and reconstruction works, staff members involved in renovating particular films and the extent of their work. One exhibition, that accompanying Pan Tadeusz, included a museum object - a historic artefact. These were pieces of film stock (made of several previously digitalised frames) which became useless for archival purposes due to the extent of damage and the fact that the same fragments were better preserved in another copy of the film. These fragments were presented at the cinema together with the digital exhibition to help viewers understand the amount of effort involved in piecing the film together. The viewers would still remember these fragments a couple of months after the event, which shows the important role of material objects in mediating audiovisual heritage.

Official screenings were often accompanied by promotional and informative leaflets. Re-premieres involved special brochures modelled on theatre brochures. A wider circulation of these materials might remedy the lack of digital equipment

3 At present, the website is no longer in use [editor's note]. 
in some cinemas where the films were screened. Sharing these brochures would make for a more democratic distribution of audiovisual heritage by the National Film Archive.

Official events focused on pre-World War II cinema also involved other attractions. The re-premiere of Pan Tadeusz was accompanied by screenings of Mania and four partially-reconstructed sound films. There were also lectures on aspects such as film costumes or sound registration techniques in pre-World War II cinema as well as workshops, addressed mainly at children and focused on film archive work. Popular lectures were given not only by the National Film Archive staff members but also invited specialists and a person whose life was influenced by the film's creation, Joanna Puchalska, a great-granddaughter of the owner of the manor house where the film was shot. All the abovementioned events were addressed at interested people professionally unrelated to the film industry. In contrast, the re-premiere of Zew morza coincided with the Nitrofilm project conclusion, accompanied by the international conference "Digital vs. Original. A New Source of History", attended by specialists and film archive staff working predominantly with the oldest cinematic works.

The atmosphere of the workshop for children can be well deduced from the following statement:

We had a $9.5 \mathrm{~mm}$ film projector, a tiny amateur thing from the $1920 \mathrm{~s}$ but still working; the kids could operate the crank and project films onto a screen. They had so much fun doing that and they could see exactly what film stock looks like and how it all works. [...] What they enjoyed most was the very act of handling the crank; they were so excited to see that it is possible to move it slower or faster and sometimes the stock would fall off if someone pulled too roughly. It was all about experiencing it first-hand, feeling that they had an impact (Interview no. 29, 2014).

The workshop for children was focused on sharing the knowledge on film as cultural heritage through experience rather than listening about it. Having physical contact with film stock was meant to guarantee understanding of the nature of the medium; materiality was thus of crucial importance. Workshop participants were to understand the amount of effort involved in preparing old films to be redistributed. As a result, they would better understand the complexity of works and become more likely to perceive reconstructed films as artefacts and historic objects; this, in turn, would add more value to such films, even if potential viewers would find them somewhat lacking in artistic quality.

The Internet is a crucial source of knowledge about the Nitrofilm project and pre-World War II films. Launching a website documenting the project's progress was one of the basic requirements for obtaining funding. As a result, the website Nitrofilm.pl features information regarding the project itself as well as film conservation, digitalisation, re-premieres and NitroAction aimed at discovering more copies of old films. Again, one may notice that working with film stock is regarded 
as one of the most important elements of knowledge on this type of heritage. To a large extent, information posted on the website is concerned with the material aspect: film stock and its conservation, rather than with the artistic quality of films.

For all the interviewed viewers, accessing audiovisual heritage covered by the Nitrofilm project was a remarkable experience. The re-premieres were treated as memorable events, often a chance to fulfil one's aspirations. Experiencing heritage was possible only through full immersion in a multi-layered event. This can be treated as an example of modern event culture, in which people expect multisensory experiences. Thus, newly created worlds were meant to stimulate in a varied manner as well as bring educational value (Szlendak, 2010, p. 93). In the Nitrofilm project, that value lies in having contact with a historic object, a historic artefact, that is a pre-World War II film recorded on film stock. Even if such a film is not remarkable for its artistic value, it can still be important because of its history. Those viewers who focused especially on this historic aspect (rather than the artistic value of a film) focused mostly on the presentation of the historic period. They analysed fashion, architecture, interior design, characters' behaviour and storytelling conventions. For this group, the additional information was not important; what mattered most was the historical information transmitted by the film itself. This is an example of heritage becoming an exhibition of itself, representation of its own past (Kirshenblatt-Gimblett, 2004, p. 2). As a result, those films gained status as artefacts (Kirshenblatt-Gimblett, 2004, p. 8) and historical sources in their own right.

\section{Moving Closer to the Original - the Category of Authenticity in Films and Film Screenings}

Authenticity, understood as being consistent with original films, was an important aspect for the viewers. As a result, screenings of pre-World War II films (especially re-premieres ) were sometimes organised as replicas of screenings of the period (and therefore accompanied by live music). As Stephen Gaps points out, in the context of historical reconstructions authenticity is understood as "proximity" to an original item; hence, apart from reproducing the greatest possible number of historic facts and details, it is essential to create the right atmosphere through alluding to appropriate "mental sensibilities" (Gapps, 2002, pp. 67-68). Thus, we have two possible interpretations of authenticity: on the one hand, it refers to authenticity of experience, while on the other, to similarity to the original historic object/event. In the case of the Nitrofilm project, the latter is difficult to establish because of the impossibility of defining that original work precisely in the case of many Polish pre-World War II films. With time, a third approach emerged, based on a musicological analogy (performing a piece of music); in this kind of analysis one may refer to Claude Lévi-Strauss's analysis of myth and its many variants, all representing the same kernel structure (Lévi-Strauss, 1968). Reconstructed films are separated from their original medium; in this respect, they are similar to images of paintings that are no longer on canvas. Still, in this line of thinking, works 
of art are inextricably linked with their physical media and each intervention influencing a medium impacts on the work of art itself. As far as digitally reconstructed pre-World War II films are concerned, heritage can be understood as films and their decay, both being part of a whole that needs to be preserved. In this approach, decay is viewed as valuable in its own right, representing the work of art's history.

Theoretically, in the case discussed above, authenticity should be easily verifiable through comparing digitalised film with the material recorded on film stock. Nevertheless, the medium is different; what is more, many films were preserved in more than one copy. Particular scenes may differ from copy to copy and the extent of decay is not the same either; that's why the degree of decay/preservation is treated as less important than the mark of passing time. The need for preserving marks of time or even creating them from scratch is discussed by Umberto Eco in his commentary on selling stylised "historic" souvenirs (Eco, 1996, pp. 19-20). Some of the interviewed viewers (5 people) advocated only partial reconstruction:

The film is old, so what I'm trying to say is that they don't have to repair everything. There can be some scratches, small marks, etc.; it doesn't have to be all bright and shiny and spotless. There should be some damage, I mean, after all, it's an old film and it should look old, too. [...] I think that they should only repair those blemishes that make it impossible to watch some scenes; for sometimes the damage is extensive, that's true (Interview no. 3, 2013).

In some situations the original can be understood as film in the same form in which it was first created. Unfortunately, there is no way to verify how close the reconstructed work is to the original material. There are no negatives of pre-World War II films, no scripts, only very few lists from a censor. In the case of silent films, there is no information regarding the original speed of projection. As a result, despite the fact that theoretically it is a case of "cool" authentication (Selwyn, 1996, pp. 6-7), much information remains impossible to verify in the light of the current knowledge of Polish pre-World War II cinema. The viewers often expressed their desire to watch the original, which they understood as the film as it was first made by its director. For this reason, some of them (9 people) accepted reconstruction works, if they resulted in bringing the film closer to its original shape through removing time marks.

This approach, in which the original film is understood as the director's original creation is linked to the conviction that the original film is what a pre-World War II audience could see in cinemas. In an ideal world these two interpretations would overlap. In fact, however, the final version of a film was often influenced by censorship and artists were seldom offered a chance to respond to a censor's cuts (a notable exception would be Córka Generata Pankratowa [General Pankratov's Daughter, 1934, dir. Józef Lejtes, Mieczysław Znamierowski], in which some scenes were added). In addition, there were interventions caused by damage inflicted during screenings. Whenever film stock was torn or damaged so much 
that it could no longer be safely used, the damaged part was removed from the reel and the remaining stock was pieced together as it was. As a result, different people watching the same copy (or even the same people watching the same copy a few days apart) could see different versions of the film. Sometimes the difference would be small (if only a few frames were removed) but occasionally, the change could influence their interpretation of the film.

Yet another approach, uniting the former two to some extent, solves the issue of the potential existence of inauthentic films and screenings. Every reconstruction and every copy of the film are here treated as separate "performances" of a work of art. For this reason, they should be analysed separately and the most important work of art is the one invented and produced by the artist themselves. A telling analogy is again one with myth as understood by Lévi-Strauss, in which a structure (langue) is produced in different versions depending on situation ( $p a-$ role). Analogically, the medium containing the original material can be viewed as langue, while all effects of reconstruction become various representations and despite their differences, all can be viewed as authentic. In this respect, originality cannot be applied in talking about films, but only with respect to the object - the film stock. All subsequent versions can then be discussed in terms of authenticity; these would function as independent interpretations of a work, representations, and partially even new works of art in their own right. With respect to music, Krzysztof Moraczewski described this phenomenon in the following way: "every rhythmic value, every articulation mark was carefully placed, and yet musicians find enough 'space' to apply their individual touch, though never in such a way as to interfere with Beethoven's text. Their discipline is neither their whim nor a need to conform to authoritarian measures of the deceased composer; rather, it is a conditio sine qua non of reproducing the work and its effect" (Moraczewski, 2012, pp. 103-104). In the case of pre-World War II films, this "text" can be understood as frame sequence, while the extent of damage, shades, projection speed and music leave scope for modern artists' creativity.

"The here and now of the original underlies the concept of its authenticity, and on the latter in turn is founded the idea of a tradition which has passed the object down as the same, identical thing to the present day" (Benjamin, 2008, p. 21). Because of that "here and now" and that "tradition", the question of authenticity of a screening remains pivotal for authenticity of a film, and that is because most viewers will only evaluate authenticity in the context of the screening in which they participated. The authenticity of such an event is hot-emotional rather than coolrational, while the "imagined tradition" remains essential and serves as a point of reference in terms of the viewers' expectations being fulfilled (Wieczorkiewicz, 2008, p. 41).

Part of the pre-World War II film screenings is organised digitally, while another part (smaller) in an analogue way. In most viewers' opinions, projections using film stock would be "perfect", as the least "inaccurate"; in addition, such screenings would become "spectacles" in their own right. The physical presence 
of a film projector allows for a deeper experience of watching old films, enabling the audience to understand the specificity of that technology and confront their expectations regarding this practice. The film itself would then be of secondary importance; what matters most are emotions.

All interviewed audience members stressed the importance of music. Unfortunately, due to the lack of records, it is impossible to assess the authenticity of new music accompanying Polish silent films. Discussing cool, objective authenticity is out of the question, for no sheet music has been preserved; therefore the role of music lies in creating atmosphere and appealing to emotions. In order to refer to the music of the era, the music accompanying modern screenings of silent films is mostly classical, compliant with popular imaginings regarding the period. As a result, it enables viewers to experience heritage more fully, by giving them a product they expect. Watching an "old" film, they listen to "old" music and in this way the right atmosphere is evoked and viewers' expectations are fulfilled. It should be noted, however, that some silent films, especially those presented during the Silent Cinema Festival, are accompanied by modern music. The atmosphere thus created enables viewers not so much to access heritage and the past but rather experience a film as a work of cinematic art. In both cases, "hot" authenticity is produced, which caters to various needs and expectations of viewers.

\section{Concluding Remarks}

Preserving the past requires adjusting historic items to new times and conditions. If pre-World War II films stored in the National Film Archive had only been preserved and had not been edited in a way making them suited to modern sensibilities, they would most likely have been forgotten. To gain heritage status, they need to conform with the times so that modern viewers can find in them what they are looking for.

Owing to the Nitrofilm project, Polish pre-World War II audiovisual heritage was produced, prepared and fixed (through circulation). Knowledge about the films was gained, used and transmitted by the staff of the National Film Archive and the Iluzjon cinema, who created a museum through their institutionalised actions. The National Film Archive staff taking part in the Nitrofilm project believed in the educational role of the museum, understood as information sharing and direct transmitting of knowledge. For some viewers, however, this approach was not attractive enough. Instead, they expected film screenings - though the films did not have to represent high artistic value - or participation in a special event. They wanted to experience the early days of cinema but they felt that in order to do this films alone are sufficient, with no need for further educational input.

In contrast, some of the other viewers shared the specialists' opinion. They treated pre-World War II films as heritage and wanted to view them as such. For them, screenings were occasions to experience historic artefacts and these, in their 
view, should be placed at the centre of all such events. For this group, educational purpose would be best achieved if films were presented without reconstruction, with all their imperfections.

For nearly all viewers, including those working professionally with pre-World War II films (interestingly, while switching roles from viewers to specialists, their opinions would change as well), the most important aspect for evaluating authenticity was experience. They were looking for an authentic experience and they evaluated screenings individually, in a hot (emotional) way. This corresponds to the current interest in the past as a way of collecting unique and authentic experiences and standing out from the crowd. Products offered by the National Film Archive, including film screenings, allow people to feel special and address their need for entertainment, while remaining historic artefacts. Most viewers are attracted by their historic quality rather than artistic value. Each film's history is unique, and often quite exciting owing to the aura of mystery surrounding the fates of particular film reels. The films are often damaged and little known, hence the complete history of a reel is usually impossible to recreate. Sometimes whole decades are left blank, which appeals to the audience's imagination. Such was the case with the copy of Pan Tadeusz found in Wroclaw.

The current wave of interest in the past is different from earlier ones; it is characterised by fleetingness, easy access and lack of desire for any deeper involvement. Heritage guarded by the National Film Archive is easily accessible; it suffices to attend a film screening or watch a film at home, which does not take more than two hours. This bears a resemblance to the current popular interest in history and being "retro" based on easily consumed elements which do not require any prior preparations, just like historical reconstructions of battles. The "retro" fashion is also present on the consumer goods market and in advertising, where fractions of the past can be bought instantly or acquired together with another product (nevertheless, this instance is devoid of the educational component).

Through its mission as a Cinematic Art Museum, the Iluzjon cinema circulates film heritage and educates about its value. It seems very likely that soon enough pre-World War II films from the collection of the National Film Archive will be able to exist in the public space in some new form, due to changes in the understanding of heritage.

\section{Bibliography:}

Benjamin, W. (2008). The Work of Art in the Age of Its Technological Reproducibility, and Other Writings on Media. Cambridge, MA - London: Harvard University Press.

Umberto, E. (1973-1983). Semiologia quotidiana.

Gapps, S. (2002). Perfoming the Past: A Cultural History of Historical Reenactments. Sydney: University of Technology.

Kirshenblatt-Gimblett, B. (2004). From Ethnology to Heritage: The Role of the Museum. https:// www.researchgate.net/publication/238714489_From_Ethnology_to_Heritage_The_Role_of_ the_Museum (access: 14.09.2017). 
Lévi-Strauss, C. (1972). Structural Anthropology. Transl. C. Jacobson. Harmondsworth: Penguin Books.

Moraczewski, K. (2012). Kultura, pamięć i muzyka, [in:] B. Jastrzęski et al. (eds.), Kultura: pamięć i zapomnienie. Księga poświęcona pamięci Profesora Piotra Kowalskiego. Wrocław: Wydawnictwo Uniwersytetu Wrocławskiego.

Nitrofilm.pl. http://www.nitrofilm.pl/.

Pantadeusz.tvp.pl.

Pieńkowski, M. (2016). „Pan Tadeusz”- making of, [in:] A. Fabianowski, E. HoffmannPiotrowska (eds.), Pan Tadeusz. Poemat-Postacie-Recepcja. Warszawa: Wydawnictwa Uniwersytetu Warszawskiego.

Selwyn, T. (1996). The Tourist Image: Myths and Myth Making in Tourism. Chichester: Willey\&Sons.

Sujecki, J. (2005). Muzeum: światynia nudy czy źródto inspiracji?, [in:] A. Szpociński (ed.), Wobec przesztości. Pamięć przesztości jako element kultury wspótczesnej. Warszawa: Instytut im. Adama Mickiewicza.

Szlendak, T. (2010). "Wielozmysłowa kultura iwentu." Kultura wspótczesna, no. 4 (66).

Wieczorkiewicz, A. (2008). Apetyt turysty: o doświadczeniu świata w podróży. Kraków: Universitas.

Interviews conducted by the author with staff members from the National Film Archive members and pre-World War II film viewers in 2013-2015:

Interview no. 1 (2013), 11 December.

Interview no. 3 (2013), 13 December.

Interview no. 29 (2014), 23 October.

\section{Summary}

This article describes the educational actions (including the use of them in education) related to pre-war films conducted by the National Film Archive in Warsaw. First to exemplify this phenomenon, I focused on the works of three silent films: Mania. The history of a cigarette factory worker (Mania. Die Geschichte einer Zigarettenarbeiterin, 1918, directed by Eugen Illés), Pan Tadeusz ([Sir Thaddeus, 1928, directed by Ryszard Ordyński) and Zew morza ([The call of the sea], 1927, directed by Henryk Szaro), which have undergone a complete digital reconstruction during the Nitrofilm project (2008-2014) in the National Film Archive. The aim is to show how knowledge about silent film is communicated to the audience, and how these movies can be used to achieve educational goals/targets. The theoretical framework of this essay is examining the changing function of film archives, where technological change, the possibilities of restoration and digitisation of films contributes to increasing popularisation of audiovisual heritage by film archivists and museums. An essential category in this essay is the authenticity both for the reconstructed film and its presentation. The perception of authenticity often determinates strategies for presentation of this heritage. The article is based on qualitative research (interviews with the audience and workers at the film archive; participant observation, press materials and websites).

Keywords: film literacy, film education 